\title{
Cross-country differences in the contribution of future migration to old-age financing
}

\author{
Johannes Berger ${ }^{1}$. Thomas Davoine ${ }^{2}$. \\ Philip Schuster $^{3}$. Ludwig Strohner ${ }^{1}$
}

(C) The Author(s) 2016. This article is published with open access at Springerlink.com

\begin{abstract}
As life expectancy increases and fertility declines, population aging puts pressure on the financing of welfare states in Europe and other developed countries. Given that immigrant workers are younger than the domestic population, a continuous flow of immigrants reduces the old-age dependency ratio and improves financing. Existing general equilibrium estimates of the public finance contribution of migration, performed with different models, are not comparable across countries and sometimes differ even in sign. We use the same overlapping-generations model with a detailed representation of institutions and labor market activity to provide comparable estimates of the impact of immigration on public finance in four European countries. We find that future projected immigration flows are equivalent to $14.3 \%$ points labor income taxes in Austria, 7.3 points in Germany, 6.2 points in the UK and 1.7 points in Poland in 2060. These differences are due to the projected volume of immigration and institutional
\end{abstract}

Electronic supplementary material The online version of this article (doi:10.1007/s10797-016-9394-3) contains supplementary material, which is available to authorized users.

$凶$ Thomas Davoine

davoine@ihs.ac.at

Johannes Berger

johannes.berger@ecoaustria.at

Philip Schuster

philip.schuster@oenb.at

Ludwig Strohner

ludwig.strohner@ecoaustria.at

1 EcoAustria - Institute for Economic Research, Am Heumarkt 10, 1030 Vienna, Austria

2 Institute for Advanced Studies, Josefstaedter Strasse 39, 1080 Vienna, Austria

3 Office of the Austrian Fiscal Advisory Council, c/o Oesterreichische Nationalbank, Otto-Wagner-Platz 3, 1090 Vienna, Austria 
setups, among other factors. For comparable volumes of immigration, future flows have largest impact in Germany and smallest in the UK.

Keywords Immigration · Population aging · Social security financing · General equilibrium · Cross-country comparisons

JEL Classification D58 $\cdot$ E60 $\cdot$ H55 $\cdot$ J11 $\cdot$ J21 $\cdot$ J61

\section{Introduction}

Driven by drops in fertility and increases in life expectancy, population aging puts pressure on the financing of pensions and other social security expenditures. Immigration is a topic of policy debate not only for social reasons, but also for economic ones. Immigrant workers could help deal with current labor supply shortages in booming sectors of European economies (Zimmermann 2005). Younger than average, they reduce the old-age dependency ratio, ${ }^{1}$ which can help deal with the financing challenge of old-age expenditures (Borjas 1994). Using different macroeconomic models, existing country-specific studies provide disparate estimates of the financial contribution of migration. Our goals are to provide comparable general equilibrium estimates for four representative European countries and to investigate the role of demographic, labor markets and institutional factors in cross-country outcome differences.

According to demographic projections from Eurostat (2011), the old-age dependency ratio in the European Union should rise from $26 \%$ in 2014 to $53 \%$ in 2060. With a smaller share of workers, an increasing number of retirees and a moderate pace of social security reforms, population aging creates a financing challenge for the typical pay-as-you-go pensions systems in Europe, as well as health and long-term care expenditures. According to the Ageing Working Group (2012), total old-age social security expenditures should increase $4 \%$ points of GDP in the European Union between 2010 and 2060. Without migration, the old-age dependency ratio would increase even more, to $61 \%$. The long-term financial contribution of immigration to old-age financing however varies across countries, due to differences in immigration volumes, institutional settings, workforce composition, immigrant skill levels and other factors. Long-term macroeconomic financial incentives associated with immigration thus vary across countries, influencing immigration-related policy in various degrees. As a response to the 2015 European refugee crisis, several countries have been lobbying for an increase in the degree of coordination of national-level immigration policy. Consistent quantitative estimates of the financial contribution of immigration are thus required for policy comparison and to inform policy makers involved in coordination.

Although estimates exist for a number of countries, they are provided in different studies using different models. Table 1 provides an overview of relevant quantitative estimates available in the general equilibrium literature and shows their disparity. For instance, Schou (2006) predicts that immigration has a negative impact on public

\footnotetext{
1 The old-age dependency ratio is the ratio of the population older than 65 years over the population aged between 15 and 64 years.
} 
Table 1 Estimates of migration long-run impacts with population aging

\begin{tabular}{llcccc}
\hline Country & Source & \multicolumn{2}{l}{ Long-run effects of yearly migration shock of $-0.1 \%$ of population } \\
\cline { 3 - 5 } & & $\begin{array}{l}\text { GDP/capita } \\
(\%)\end{array}$ & $\begin{array}{l}\text { Labor tax } \\
(\% \text { points })\end{array}$ & $\begin{array}{l}\text { Consumption } \\
\text { tax }(\% \text { points })\end{array}$ & $\begin{array}{l}\text { Pension deficit } \\
(\% \text { points GDP) }\end{array}$ \\
\hline Denmark & Schou (2006) & 0.9 & & -0.1 \\
Italy & Magnani (2011) & & 2.5 & 0.6 \\
Spain & Izquierdo et al. (2010) & -2.2 & 2.4 & 1.7 \\
Europe & Fehr et al. (2003) & -13.3 & 0.3 & \\
USA & Storesletten (2000) & & 0.7 & \\
USA & Fehr et al. (2003) & -11.8 & & 0.3 \\
USA & Chojnicki et al. (2011) & 0.4 & & \\
\hline
\end{tabular}

Changes in GDP per capita, taxes and pension deficit after 50 years, normalized to the same migration shock ( $-0.1 \%$ of population) assuming proportional impacts; only general equilibrium analysis for Europe and the USA are considered in the table

finance in Denmark while Izquierdo et al. (2010) find a positive impact for Spain. Whether these differences come from modeling choices or from country characteristics is unclear, which makes cross-country comparisons problematic and policy making coordination difficult. ${ }^{2}$ One of our contributions to the literature is to provide a set of consistent estimates for four representative European countries, Austria, Germany, Poland and the UK, suitable for policy comparison and coordination.

In order to provide consistent estimates for different countries, we use the same overlapping-generations model calibrated for each country. The model is standard but rich to accommodate differences in institutional settings and labor markets across countries. In particular, the pay-as-you-go pension system, with flat and earningsrelated parts, captures financial incentives for postponed retirement. As the skill distribution of immigrant and native populations differ, households are separated into three skill classes. Because social security contributions and benefits depend on labor market status in different ways in different countries, the labor market is modeled in detail. Specifically, the labor market is imperfect and households choose education into one of three skill levels, as well as labor market participation, job search efforts if unemployed and work hours if employed. Migration in and out of the country is exogenous. In line with empirical evidence, foreign workers have worse prospects on the labor market even at equivalent skill level, which we model with exogenous and constant penalties.

We find that future immigration flows, as projected by Eurostat (2011), have different contributions to old-age social security financing across countries. Projected immigration flows after 2015 are equivalent to $14.3 \%$ points labor income taxes in Austria, 7.3 in Germany, 6.2 in the UK and 1.7 in Poland for a comparable public finance position in 2060. As immigrants are younger, a permanent immigration inflow raises the proportion of households who are in the contributing phase of their life and decreases the proportion of households who are in the benefit phase of life. The resulting broadening of the tax base allows for a relative reduction of the tax rate.

${ }^{2}$ Fehr et al. (2003) provide estimates for Japan, the US and Europe as a region which can be compared. 
One obvious reason for cross-country differences is that projected immigration volumes differ, being about three times larger for Austria and the UK than for Germany, and eight times larger than for Poland, relative to population size. This is however not the only reason. Hypothetically assuming relative future immigration volumes as in Germany for all countries, immigration is equivalent to $5.7 \%$ points labor income taxes in Austria, 3.9 in Poland and 2.1 in the UK, compared to 7.3 in Germany. Another factor is differences in institutions. For instance, the pension system in the UK has a Beveridgean nature with a focus on minimum income, while Germany has a Bismarckian pension system with a strong earnings-related part, which is more expensive. With identical immigration volumes, public finance gains are more limited in the UK than in Germany because the pension system is comparatively cheaper. Further contributing factors are the age structure of the population, the distribution of skills and the production structure.

From a policy perspective, our results provide another rationale for cross-country differences in immigration policy. Mayda (2006) empirically finds that labor market concerns, along with noneconomic factors, are related to differences in attitudes toward immigration across countries. Our study suggests that public finance concerns due to population aging represent another economic factor behind immigration policy heterogeneity: some countries benefit more over the long-term from immigration than others.

The paper continues with four sections. In Sect. 2, we document stylized facts on the demographics, migration and labor markets in Europe and explain our choice of representative countries. In Sect. 3, we present the model. Results of our quantitative investigations are contained in Sect. 4. Policy implications are derived in the following section. Section 6 concludes.

\section{Stylized facts and country sample}

With low fertility and a decline in mortality, many developed countries are confronted with a rapidly aging population. Based on demographic projections from Eurostat (2011), the old-age dependency ratio in the European Union should rise from $26 \%$ in 2014 to $53 \%$ in 2060. European countries however are not exposed to population aging to the same extent: the old-age dependency ratios should increase from 28 to $46 \%$ (a $64 \%$ increase) in Sweden but jump from 17 to $62 \%$ (a $264 \%$ increase) in Slovakia between 2010 and 2060.

The dependency ratio increase puts pressure on the financing of the welfare state with stable retirement ages, as the ratio of workers over retirees drops. According to the Ageing Working Group (2012), European Union expenditures on pensions, health and long-term care will increase by $4 \%$ points of GDP between 2010 and 2060.

Immigration could have a positive impact on public finances of aging countries, because immigrants are younger on average than the native population, which mitigates the drop in the ratio of workers over retirees. Volume of immigration however differs across countries, Eurostat (2011) projections ranging from negative values (net emigration) in Baltic states to a yearly average of 16 immigrants per 1000 inhabitants in Luxembourg between 2010 and 2060. 

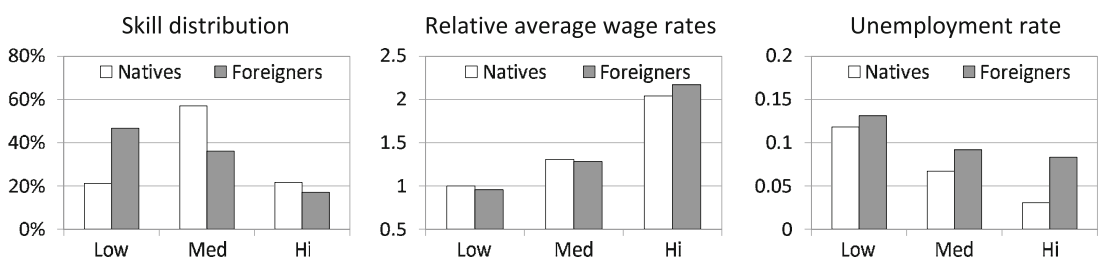

Source: LFS, EU-SILC, own calculations

Fig. 1 Labor market integration of natives and foreigners by education level, Germany

To reach our goal of quantifying the long-run public finance contribution of immigration, we use a general equilibrium model calibrated for a representative selection of European Union countries. The selection is made along three criteria influencing the financing contribution of immigration: population aging speed, projected volume of immigration and pension system type. ${ }^{3}$ The resulting selection is Austria, Germany, Poland and the UK.

Austria has a Bismarckian pension system, is not aging fast and is exposed to large immigration flows. The same holds for Germany except it is not exposed to large immigration. Poland also has a Bismarckian system, but is aging fast and is not exposed to large immigration. The UK has a Beveridgean pension system, is not aging fast and is not exposed to large immigration. Other countries with Beveridgean pensions are no different. ${ }^{4}$

To what extent immigration supports the long-term financing of social security depends on the integration of immigrants in the labor market. In general, the literature finds that most immigrants incur a penalty (see e.g., Algan et al. 2010). Figure 1, based on LFS and SILC microdata, provides an illustration for Germany. ${ }^{5}$ These labor market characteristics, which are country-specific, will be taken into account in our model and its calibration.

\section{Model}

Overlapping-generations models have been typical tools for the analysis of the effect of population aging on public finance, ever since Auerbach and Kotlikoff (1987). Population aging is indeed a slow process and these models operate in general equilibrium, of particular interest for long-run impacts without price rigidity (Buiter 1997). At the core of the demographic process is the modification of the age structure of the population, for which overlapping-generations analysis is well suited. The main modeling cost is the reliance on (families of) representative agents, which render the models ill suited for the analysis of distributional effects. In our case the cost is limited, given

\footnotetext{
3 We consider that a country is aging fast if its dependency ratio increases $150 \%$ or more and that it is exposed to large immigration flows if the projected yearly inflows average more than $0.5 \%$ of the population between 2010 and 2060 .

4 For further details on the selection procedure see appendix A, available online.

5 A person born in Germany is defined as native. Low skill is a person with 1997 ISCED education levels 0-2, medium skill levels 3-4 and high skill levels 5-6. See the online appendix A for details and figures for Austria, Poland and the UK.
} 
the aggregate nature of our research question, concerned with macroeconomic and public finance outcomes. Note also that overlapping-generations approaches assume that the microempirical estimates used for calibration are representative of household behavior not only over the short run, but also the long run. In this paper, we use the strength of overlapping-generations but keep in mind assumptions in the interpretation of results, focusing on conservative estimates.

The paper novelty and focus is cross-country comparability. Model developments are limited to make comparisons with existing results of the literature easy. We combine relevant model features from the existing literature and add a small extension, migration.

Existing relevant model features are as follows. Data show that natives and foreigners have different labor market prospects and that differences in particular in unemployment risk depend on skill level (see Fig. 1). We therefore use a model with an overlapping-generations structure and unemployment as basis, Jaag et al. (2010). ${ }^{6}$ We add to this model three skill classes and endogenous education decisions following Heckman et al. (1998). The modeling novelty of this paper is migration, which will be presented in detail below.

For easier reading, we present the ideas of the model and refer to the technical appendix Berger et al. (2016) for details. ${ }^{7}$

\subsection{Description}

\subsubsection{Demographics}

There are nine life cycle stages spread over three consecutive phases, starting with education, continuing with work and finishing with retirement. Time periods last one year. Life cycle stages can last several time periods. Wages have a life cycle profile consistent with empirical earnings. Households differ in their nationality, learning ability, birth date, death date and the speed at which they go through the stages of the life cycle. ${ }^{8}$

At every stage $a \in\{1, \ldots, 9\}$, households face a constant probability $1-\gamma^{a}$ of dying and a probability $\gamma^{a}\left(1-\omega^{a}\right)$ of moving to the next stage $a+1$, with $\omega^{9}=$ 1. Households can stay in stage $a$ several time periods. The conditional probability $1-\omega^{a}$ defines how quickly households move from one stage to the other, on average. Following Blanchard (1985), a reverse life insurance allocates assets at death. At stage $a^{R}$ households choose their retirement date.

\footnotetext{
6 There exist two other overlapping-generations analyses of population aging with unemployment in the literature. Annabi et al. (2009) however assume inelastic labor supply, while pension benefits are independent of unemployment history in de la Croix et al. (2013). Jaag et al. (2010) avoid these limitations.

7 The technical appendix is available upon request.

8 Speed differences lead to a stochastic life cycle structure, an extension to several age classes of the two-age class stochastic structure of Gertler (1999). Analytical aggregation results, summarized below, remove this degree of heterogeneity in the implementation. For ease of presentation, we use a simplified notation which neglects this degree of heterogeneity. See Jaag et al. (2010) for a motivation and the technical appendix Berger et al. (2016) for a presentation with the exhaustive notation.
} 
We use an implementation where the average durations of stay in each life cycle stage correspond to ages $15-19,20-24,25-34,35-44,45-54,55-69,70-79,80-84$ and $85+$. We later use interchangeably the words "life cycle stage" and "age group". The threshold stage is $a^{R}=6$. Stages $a \in\{7,8,9\}$ are full retirement stages but with different probabilities of dying $1-\gamma^{a}$, to better replicate the empirical age structure of the population.

Households have different nationalities. Consistent with empirical evidence presented in Sect. 2, foreigners have different labor market prospects than natives. A person with domestic citizenship is called a native ( $n=D$ for domestic citizenship) and a person who immigrated in the country and does not have citizenship is called a foreigner ( $n=F$ for foreign citizenship). ${ }^{9}$ Children of foreigners eventually become citizens, having then different labor market prospects than their parents. For simplicity, we assume that only children of foreigners can acquire citizenship, at an assimilation rate defined exogenously.

Households have different learning abilities and choose education efforts to end up with one of three skill levels, $i \in\{l, m, h\}$, low, medium or high.

We allow for differences in fertility rate by age class and nationality. Our model also allows for partial inheritance of learning ability which differs by nationality, consistent with Borjas (1992). These exogenous parameters define the number of labor market entrants in each period.

\subsubsection{Households}

In each period, risk-neutral households make consumption and labor market-related decisions in order to maximize expected lifetime utility. Preferences are represented with the utility theory developed by Weil (1990), restricting individuals to being riskneutral but allowing for an arbitrary intertemporal elasticity of substitution: ${ }^{10}$

$$
V_{t}^{a}=\max \left[\left(Q_{t}^{a}\right)^{\rho}+\gamma^{a} \beta\left(G \omega^{a} V_{t+1}^{a}+G\left(1-\omega^{a}\right) V_{t+1}^{a+1}\right)^{\rho}\right]^{1 / \rho}
$$

where $V_{t}^{a}$ is the expected remaining lifetime utility of a household in life cycle stage $a$ at time $t, \rho$ defines the elasticity of intertemporal substitution $1 /(1-\rho), \beta$ is a time discounting factor, $Q_{t}^{a}$ is effort-adjusted consumption (as per the definition provided below) and $G=1+g$ is the gross factor of growth by which the model is detrended.

Migration is modeled as an exogenous event, following an idiosyncratic shock: we assume that economic prospects in the destination country are the same as in the origin country, leaving households indifferent between migrating or not (consistent with the long-run outcome of the two-sided migration analysis from Sinn 2000). When migration takes place, households carry financial assets and pension rights over the border.

\footnotetext{
9 Our definition of citizenship does not correspond to the legal definition and should be taken as an economic definition of citizenship. For ease of reading, we only write citizenship.

10 For a lighter notation, we suppress the skill $i$ and nationality $n$ indices when they are not needed, and only use the age class index $a$ systematically, in the continuation.
} 


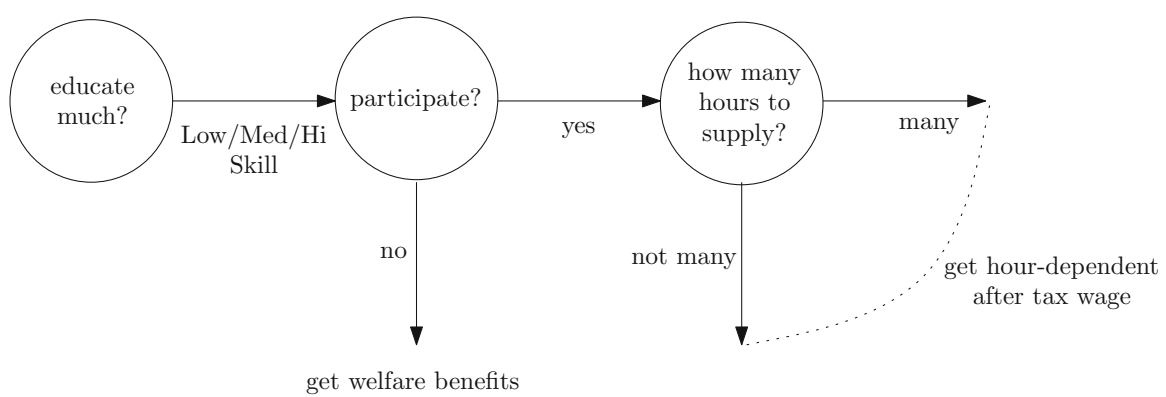

Fig. 2 Sequence of household decisions related to the labor market

Households take a number of decisions related to the labor market, as illustrated in Fig. 2. Before entering the labor market, households choose their education level, depending on the learning ability they are given at birth and future expected earnings. They enter the labor market in life cycle stage $a=1$ if they do not educate beyond compulsory school (respectively, $a=2$ for a medium skill education and $a=3$ for a high skill education). After entering the labor market, they decide whether to participate or not $\left(\delta^{a} \in[0,1]\right.$ represents the fraction of time they participate $\left.{ }^{11}\right)$. Following Jaag et al. (2010), we consider that non-participation during the retirement period $a^{R}$ is equivalent to retirement and assume that the institutional setting forces households of the same age, skill and nationality class to choose the same retirement date based on average earnings, regardless of differences in earning history. As a simplification needed for aggregation results, this assumption nonetheless captures dimensions of the institutional settings which generate bunching in retirement decisions, such as penalties for early retirement (French 2005). Households who work decide how many hours to supply $\left(l^{a} \geq 0\right)$.

Households choose consumption $C^{a}$ in every period. Labor and consumption tradeoffs are defined by preferences and the effort-adjusted consumption

$$
Q_{t}^{a}=C_{t}^{a}-\bar{\varphi}^{a}\left(\delta_{t}^{a}, l_{t}^{a}\right)
$$

where $\bar{\varphi}^{a}(\cdot)$ is a convex increasing function in all its arguments which represents the utility cost of efforts related to labor market activity expressed in goods equivalent terms. Given the reverse life insurance, the intertemporal budget constraint of households is

$$
G \gamma^{a} A_{t+1}^{a}=R_{t+1}\left(A_{t}^{a}+y_{t}^{a}-C_{t}^{a}\right)
$$

where $A^{a}$ is assets, $y^{a}$ net income flows and $R=1+r$ the interest factor.

Households move through the life cycle at different speeds. Households in the same life cycle stage $a$ have in general different biographies and thus have been exposed

\footnotetext{
11 The instantaneous participation decision is binary. Over a time period, the household may however participate part or all of the period (for instance, 5 months in a 1 year time period).
} 
to different wages through their life. Their labor income profiles being different, consumption and saving decisions also differ. Within the same life cycle stage $a$, goods consumption $C_{t}^{a}$, effort-adjusted consumption $Q_{t}^{a}$ and assets $A_{t}^{a}$ thus always depend on the household biography. In Sect. 3.2, we present the numerical approach to deal with heterogeneity in biographies.

\subsubsection{Labor market and pension system}

We assume a separate labor market for each life cycle stage $a$, skill class $i$ and nationality $n$. Equal to their marginal products, wages $w^{a, i, n}$ differ in each stage, skill and nationality class but are identical for workers in the same class, taking productivity differentials into account. An age- and skill-dependent productivity parameter $\theta^{a, i}$ gives the life cycle profile of wages and captures productivity differences between skill classes. As labor market prospects for natives and foreigners differ (see Fig. 1), productivity profiles also differ between them, $\theta^{a, i, n}$. Productivity differentials $\theta^{a, i, D} / \theta^{a, i, F}$ are calibrated from wages data and kept constant over time, assuming labor market prospects of foreigners neither improve nor worsen. ${ }^{12}$

Conditional on labor market participation, gross labor income equals

$$
y_{\mathrm{par}, \mathrm{t}}^{a, i, n}=l_{t}^{a, i, n} \cdot \theta^{a, i, n} \cdot w_{t}^{a, i, n} .
$$

When workers decide not to participate in the labor market, they collect net-of-tax welfare benefits $y_{\text {nonpar,t }}^{a}$, which are independent of wages and past earnings. When workers are retired, they collect pension payments $y_{\text {pens, },}^{a}$, which mainly depend on past earnings. Denoting $\tau_{t}^{a}$ the labor income tax rate and assuming that each labor market state (i.e., non-participation and employment) is visited in each time period, ${ }^{13}$ income flows are

$$
y_{t}^{a}= \begin{cases}\delta_{t}^{a} \cdot\left(1-\tau_{t}^{a}\right) \cdot y_{\mathrm{par}, \mathrm{t}}^{a}+\left(1-\delta_{t}^{a}\right) \cdot y_{\mathrm{nonpar}, \mathrm{t}}^{a} & \text { if } a<a^{R} \\ \delta_{t}^{a} \cdot\left(1-\tau_{t}^{a}\right) \cdot y_{\mathrm{par}, \mathrm{t}}^{a}+\left(1-\delta_{t}^{a}\right) \cdot\left(1-\tau_{t}^{a}\right) \cdot y_{\mathrm{pens}, \mathrm{t}}^{a} & \text { if } a=a^{R} \\ \left(1-\tau_{t}^{a}\right) \cdot y_{\mathrm{pens}, \mathrm{t}}^{a} & \text { if } a>a^{R}\end{cases}
$$

Not only wages and labor income taxes influence labor supply, but also the pay-asyou-go pension system. Pension payments $y_{\text {pens, } t}^{a}$ indeed have a flat part, independent of past earnings and comprising anti-poverty benefits, as well as an earnings-related part. The stronger the earnings-related part, the larger the incentive for workers to provide labor supply along all margins, ceteris paribus. Pension payments are given by $y_{\mathrm{pens}, \mathrm{t}}^{a}=v^{a} P_{t}^{a}+P_{0, t}^{a}$, where $P_{0, t}^{a}$ is a flat part, $P_{t}^{a}$ represents acquired pension

\footnotetext{
12 In reality, foreign workers suffer a penalty for economic reasons (e.g., worse language skills) and for noneconomic reasons (e.g., discrimination at recruiting). The noneconomic penalty could vary over time with either improved assimilation or cultural backlash, which would affect the immigration impact on public finance, an analysis left for future research.

13 An equivalent assumption is income pooling (perfect insurance) within each age, skill and nationality class, as used for instance in the real business cycle and unemployment theory of Andolfatto (1996).
} 
rights and $v^{a}$ is a conversion factor between pension rights and pension payments. ${ }^{14}$ Pension rights can be accumulated with labor market participation, given by $P_{t+1}^{a}=$ $\delta_{t}^{a} y_{\mathrm{par}, \mathrm{t}}^{a}+P_{t}^{a}$. Building on Gruber and Wise (2005), penalties for early retirement and incentives for postponed retirement are provided during the retirement decision period with a modified conversion factor $y_{\text {pens, } \mathrm{t}}^{a}=\left(1+\sigma\left(\delta_{t}^{a}-\delta^{R}\right)\right) v^{a} P_{t}^{a}+P_{0, t}^{a}$ for age $a=a^{R}$, given a statutory retirement age $\delta^{R}$ and incentive factor $\sigma \geq 0$.

\subsubsection{Production}

There is a representative firm facing perfect competition, producing a single composite good with capital and three types of labor, corresponding to the three skill levels of workers. The production function, a linearly homogeneous nested CES function following Jaag (2009), is specified to ensure balanced growth at an exogenous rate $g$ in equilibrium steady states. Firms make investment decisions to maximize the flow of dividends they generate.

The gross interest factor $R=1+r$ is exogenous, as in a small open economy. Changes in the production process are costly variations in the capital stock and subject to capital adjustment costs, following Hayashi (1982).

There is imperfect substitution between the various types of labor. We assume capital-skill complementarity, an empirically realistic feature which can account for wage inequality variations (Krusell et al. 2000). While labor inputs from workers with different skill levels are imperfect substitutes, we consider that inputs from native and foreign workers of the same skill level conditional on productivity are perfect substitutes, consistent with Borjas (2003). ${ }^{15}$

\subsubsection{Government}

The state provides welfare benefits, pay-as-you-go pensions and investment subsidies. Government expenditures include public consumption, defined exogenously in per capita terms. They also include long-term care and health expenditures, defined exogenously in per capita and age terms.

To finance expenditures, the government collects taxes and social security contributions. The government can borrow on the capital market (without premium on the interest rate) to finance public debt, which we keep constant.

Pension payments to migrants are partially paid by the origin country and partially by the destination country, in proportion of the pension points earned in the respective countries.

\subsubsection{Equilibrium}

Under the small open economy assumption, the goods market clears via trade with the rest of the world. Holdings of foreign assets by domestic households evolve with

\footnotetext{
14 In Germany and Poland, sustainability mechanisms automatically adjust parameters of the pension system. Our simulations will take it into account.

15 Unlike Borjas (2003), Ottaviano and Peri (2012) assume imperfect substitutability. As discussed by Borjas et al. (2008), direct empirical evidence on (in)substitutability is however still inconclusive.
} 
changes in the trade balance. The asset market clears in a standard fashion, net financial assets $A_{t}^{a}$ of households being split between holdings of public debt, foreign assets and assets invested in firms.

\subsubsection{Full model}

For precise estimates in the quantitative evaluation, we use a more complete model with imperfect labor markets, public unemployment insurance and intervivo transfers, all following Jaag et al. (2010). Unemployment is due to matching frictions, using the static search framework from Boone and Bovenberg (2002). Unemployment insurance has a flat part and an earnings-related part. With joy-of-giving preferences, households derive utility from intervivos transfers. Related joy-of-giving preference parameters are calibrated to match empirical age profiles of consumption.

\subsection{Analysis and solutions}

The model is comprehensive in household decisions and institutions and cannot be solved analytically. Numerical computation will be used to find solutions. Some analytical results are however essential. Because households move through the life cycle at different speeds, their earnings histories, wealth and consumption decisions differ. One can however derive optimality conditions from the individual, history-dependent level to an age-, skill- and nationality-class level to obtain average consumption decisions within each class. This aggregation procedure allows to solve numerically the model at the class level, for a much reduced degree of heterogeneity. Details are contained in online appendix $\mathrm{C}$.

\subsection{Calibration}

The calibration follows a standard approach whose outcome is in line with literature standards. Details are contained in online appendix D.

Parameters for institutions are taken from the MISSOC database and OECD's Tax-Benefit model. Average personal income tax rates and exogenous labor market penalties for foreign workers are computed with EU-SILC microdata. European countries have enacted pension reforms with immediate or future implementation. We borrow pension parameter adjustments from the Ageing Working Group (2012), which takes these reforms into account, including sustainability mechanisms for Poland and Germany. Aggregate pension expenditures, an endogenous outcome of the model, are comparable to projections from the Ageing Working Group (2012). We take health and long-term care age-dependent expenditure projections from the same source.

We rely on empirical studies to define labor supply elasticity parameters following the literature discussion in Immervoll et al. (2007).

The education of children is influenced both by parents and by schools. The gap between these two influences can be large when parents are foreigners. A skill inheritance matrix reflects these diverse influences for children of foreigners. The gap being 
smaller for natives, their children choose their education level based on future expected earnings.

We rely on the 2010 demographic projections from Eurostat (2011) to set net migration, fertility and age-dependent mortality rates. The skill distribution in future migration flows is constant and equal to its 2010 value.

\section{Quantitative results}

This section presents the simulation results. We compare labor market, macroeconomic and public finance outcomes between 2010 and 2060 in different demographic scenarios for Austria, Germany, Poland and the UK. Namely we compare outcomes in the benchmark cases using the Eurostat migration projections with outcomes in the hypothetical case where immigration to Austria, Germany, Poland or the UK stops after $2015 .^{16}$

In all cases, we finance the increase in social security expenditures due to aging alone with lump-sum taxes. This choice delivers conservative estimates and prevents unbalanced distortion across our experiments. ${ }^{17}$

Section 4.1 presents and discusses results for each country, and Sect. 4.2 investigates factors driving cross-country differences. The impact of our methodological choices is evaluated in online appendix $\mathrm{E}$, which shows that endogenous participation margins matter and that results are robust to alternative modeling of the specific German pension sustainability mechanism. For ease of presentation, we discuss outcomes for one country alone when differences between countries do not matter. Germany is chosen for this role, because other countries have either low or high projected immigration.

\subsection{Single-country outcomes}

While the impact of immigration changes is limited in the short run, it is large in the long run. Tables 2 and 3 provide the simulation results, comparing long-run outcomes with and without immigration for Austria, Germany, Poland and the UK. We start with a presentation of the results for Germany, a presentation which also applies qualitatively to the other countries.

The right part of Table 2 displays the demographic, labor market, macroeconomic and public finance equilibrium in 2010 and four different cases in 2060 for Germany. The benchmark case (Mig column) assumes migration as per the Eurostat (2011) projections. The three other cases assume an end to immigration after 2015. In these three cases, the end of immigration leads to a net loss of public revenue. We compensate

\footnotetext{
16 We focus on the case where the border is closed to foreign workers only because it reflects best the policy debate. Sensitivity analysis where the border is closed to native and foreign workers finds smaller but comparable outcomes (unreported).

17 Increases in expenditures due to the end of immigration are financed with a different instrument in each experiment, to be detailed in Sect. 4.1. Because the disincentive effects of taxation increase overproportionally with taxes, financing population aging with distortive taxation would lead to a small distortion in some experiments and a large distortion in other experiments. Lump-sum tax financing avoids this imbalance.
} 


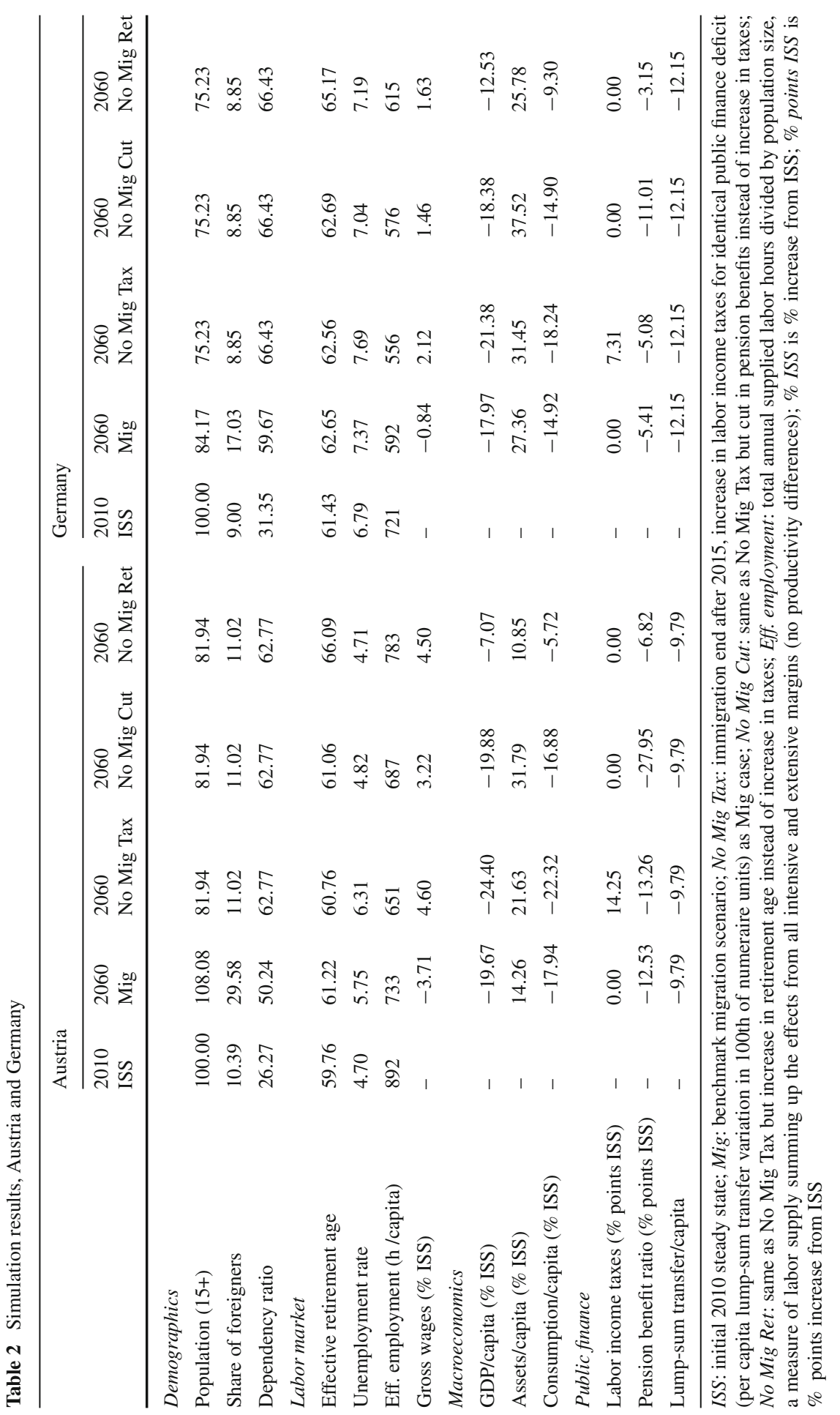




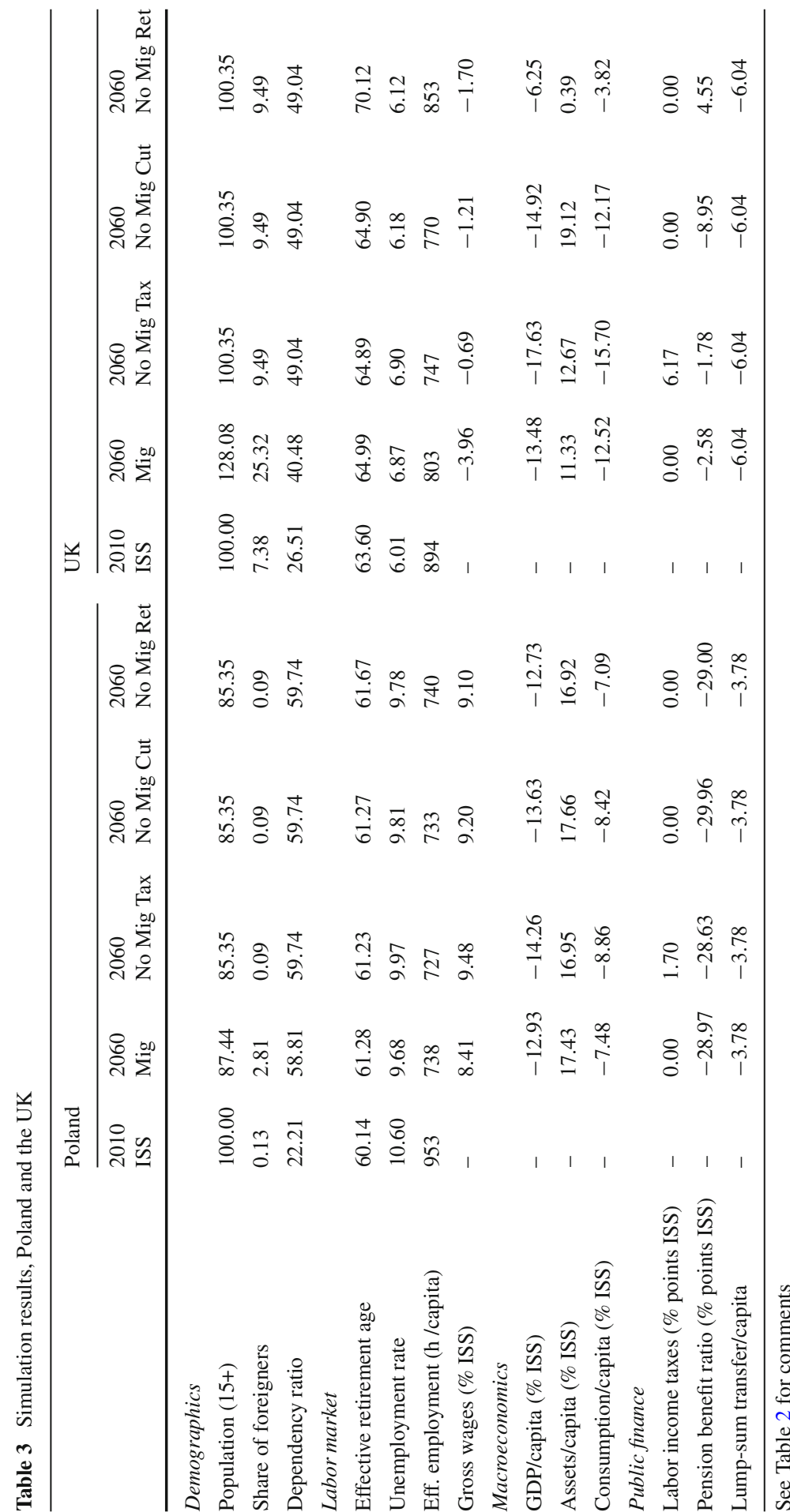


the public revenue loss with a change in the tax and social security system so that the per capita public finance position of the country is identical to the benchmark case, which we consider happens if the government budget is balanced with the same level of per capita lump-sum taxation as in the benchmark case. In one case (No Mig Tax column), the loss of revenue due to the end of immigration is compensated by an increase in labor income taxes. In another case (No Mig Cut column), the loss of revenue due to the end of immigration is compensated by a cut in pension benefits. In the last case (No Mig Ret column), the loss of revenue is compensated by an increase in retirement age.

For an identical public finance position, immigration flows are equivalent to $7.3 \%$ points lower labor income taxes (No Mig Tax), a 5.6\% points higher pension benefit ratio (No Mig Cut compared to Mig) or 2.5 years earlier retirement in 2060 (No Mig Ret compared to Mig). To illustrate the importance of these outcomes, $7.3 \%$ points of labor incomes taxes correspond to $4.7 \%$ of GDP of public revenue.

Including outcomes for all countries, the summary result of this section is:

Finding 1 For identical public finance positions in 2060, future projected immigration is equivalent to $7.3 \%$ points lower labor income taxes, $5.6 \%$ points higher pension benefit ratio or 2.5 years earlier retirement in Germany, and qualitatively similarly for Austria, Poland and the UK. Specifically, future projected immigration flows are equivalent in 2060 to...

\begin{tabular}{lllll}
\hline & Austria & Germany & Poland & UK \\
\hline Labor income tax (\% points) & -14.3 & -7.3 & -1.7 & -6.2 \\
Pension benefit ratio (\% points) & +15.4 & +5.6 & +1.0 & +6.4 \\
Retirement age (years) & -4.9 & -2.5 & -0.4 & -5.1 \\
\hline
\end{tabular}

Effects are qualitatively identical across countries but quantitatively different. To finish this subsection, we provide a discussion of qualitative effects. Because these effects are identical, we provide a discussion for Germany only. Similar conclusions apply to Austria, Poland and the UK. We investigate cross-country quantitative differences in Sect. 4.2.

Results are driven by mechanical effects, behavioral reactions and general equilibrium effects. Note also that Table 2 reveals economic differences between policy scenarios: while the public finance position is identical, the state of the economy is not. We discuss effects for the three cases without immigration.

\subsubsection{Tax increase}

Because immigrants are on average younger, the dependency ratio is mechanically higher without immigration flows ( $66 \%$ without immigration flows versus $60 \%$ with). At constant statutory retirement age (No Mig Tax case), the share of retirees and aggregate pension expenditures are thus larger without immigration flows. The necessary 
increase in labor income taxes to keep the overall per capita public finance deficit constant adds a behavior effect, as it depresses labor supply incentives along intensive and extensive margins (effective employment, which sums up labor supply effects along all margins net of demographic variations, decreases to 556 yearly worked hours per capita instead of 592) and thus social security contributions.

\subsubsection{Pension cuts}

A second option to finance the loss of revenue which comes with the stop in immigration is to reduce (earnings-related) pension benefits (No Mig Cut case). Behavioral reactions have visible intertemporal optimization dimensions, both for consumption and labor supply decisions. As pension benefits are reduced (11\% points drop in the benefit ratio in the No Mig Cut case instead of 5.4 in the Mig case), households work and save more to self-finance consumption in old age, relative to other scenarios (576 worked hours per capita and $37.5 \%$ increase in assets per capita in the No Mig Cut case instead of 556 hours and $31.5 \%$ in the No Mig Tax case).

\subsubsection{Retirement age increase}

A third option to finance the loss of revenue brought by the end of immigration is to make a reform to increase the effective retirement age (No Mig Ret case). With less workers in retirement, social security contributions increase and pension expenditures decline. The necessary increase of 2.5 years is however large. ${ }^{18}$ This outcome is driven by composition effects, general equilibrium effects and the need to finance all social security expenditures, beyond pensions. As health expenditures per capita increase with age, an older population means larger aggregate health expenditures.

Since the foreign population has lower education on average, the average worker productivity is higher when immigration is stopped, resulting in a higher marginal product of labor and higher average wages $(1.6 \%$ increase in gross wages in the No Mig Ret case versus $-0.8 \%$ in the Mig case). The earnings-related part of pension payments is thus higher, and so are aggregate pension expenditures. Because finances of the pension system are not balanced (contributions do not cover payments), these larger per capita increases in social security expenditures need to be financed with an increase in the retirement age which goes beyond equalizing the fraction of pensioners.

\subsubsection{Other comment}

In all cases, output and consumption per capita drop in 2060 between 10 and $20 \%$, relative to the productivity growth trend. Population aging leads to significant drops in labor supply per capita (from 720 hours in 2010 to 620 or less). With constant interest rates, firms keep the marginal product of capital constant by reducing investment and capital per capita in a commensurate fashion. Output then drops as much as production inputs, and consumption opportunities follow. The drop is lower when retirement age

18 Indeed, equating the fraction of pensioners is not sufficient: $41.7 \%$ of the population in the No Mig Ret case versus $42.3 \%$ in the $\mathrm{Mig}$ case (unreported numbers). 
is increased (No Mig Ret), as labor supply per capita drops less. Consumption drops however less than output per capita. Households save indeed more to maintain living standards over a longer period of time after retirement, given life expectancy increase: assets per capita are at least $25 \%$ larger in 2060 than 2010. Since the increase in the retirement period is lowest when the retirement age is postponed (No Mig Ret case), the increase in savings is lowest $(25 \%)$. The increase is largest (38\%) when pensions are cut (No Mig Cut case) because households need to compensate for the loss in earnings-related pension revenue.

\subsection{Cross-country analysis}

While the previous subsection provides and discusses the results on a single-country basis, this subsection provides an analysis of cross-country differences.

As shown in the previous subsection, the contribution of projected immigration flows to the long-run financing of old-age social security expenditures differs across countries (finding 1). An obvious reason for the difference is the projected volume of immigration, which varies across country: while immigration is projected to reach $0.43 \%$ of the total population in Austria in 2060, it is projected to reach $0.38 \%$ in the UK, $0.12 \%$ in Germany and $0.05 \%$ in Poland.

To investigate the role of immigration volumes in differences of outcomes across countries, we repeat the tax gain analysis of the previous subsection with a counterfactual migration scenario where volumes are identical for all countries. Specifically, relative to population size we assume that projected immigration volumes after 2015 in Austria, Poland and UK are the same as in Germany, whose projected immigration lay in the middle of the group.

Table 4 presents the outcomes of the experiment. Key demographic and public finance variables are reported for all four countries. ${ }^{19}$ Outcomes of simulations assuming country-specific immigration volumes (in columns Cty-Spec $\mathrm{Mig} \mathrm{Vol}$ ) are compared to outcomes assuming immigration volumes equal to volumes for Germany (in columns $\mathrm{DE} \mathrm{Mig} \mathrm{Vol}$ ). The first outcomes (in columns Cty-Spec Mig Vol) are taken from tables 2 and 3 and repeated for convenience. As expressed in finding 1, labor income taxes in Austria would have to be raised by 14.3\% points in 2060 (No Mig Tax column) if the projected volume of immigration into Austria $(0.43 \%$ of the population in 2060, Mig column) was stopped after 2015, in order to reach the same per capita public finance position with or without immigration (per capita lump-sum transfers variation of 9.8 hundreds of numeraire units in columns Mig and No Mig Tax). In other words, for Austria a yearly immigration shock of magnitude $0.43 \%$ of the population is equivalent to a $14.3 \%$ points labor tax increase in public finance terms in 2060 . Similarly, columns DE Mig Vol show that a yearly immigration shock of magnitude $0.12 \%$ of the population is equivalent to a $5.7 \%$ points labor tax increase in 2060 public finance terms in Austria. With different immigration volumes, the tax gain is larger in Austria than Germany (14.3 vs. $7.3 \%$ points). With identical immigration volumes, the tax gain is now smaller in Austria than Germany but the difference is

19 Compared to Tables 2 and 3, only the immigration volume variable is new. 
Table 4 Simulation results, country-specific and German migration volumes

\begin{tabular}{|c|c|c|c|c|c|}
\hline & \multirow[b]{2}{*}{$\begin{array}{l}2010 \\
\text { ISS }\end{array}$} & \multicolumn{2}{|c|}{ Cty-Spec Mig Vol } & \multicolumn{2}{|c|}{ DE Mig Vol } \\
\hline & & $\begin{array}{l}2060 \\
\text { Mig }\end{array}$ & $\begin{array}{l}2060 \\
\text { No Mig Tax }\end{array}$ & $\begin{array}{l}2060 \\
\text { Mig }\end{array}$ & $\begin{array}{l}2060 \\
\text { No Mig Tax }\end{array}$ \\
\hline \multicolumn{6}{|l|}{ AT } \\
\hline \multicolumn{6}{|l|}{ Demographics } \\
\hline Immigration volume (\% pop) & 0.32 & 0.43 & 0.00 & 0.12 & 0.00 \\
\hline Dependency ratio & 26.27 & 50.24 & 62.77 & 57.73 & 62.77 \\
\hline \multicolumn{6}{|l|}{ Public finance } \\
\hline Labor income tax (\% points ISS) & - & 0.00 & 14.25 & 0.00 & 5.70 \\
\hline Lump-sum transfer/capita & - & -9.79 & -9.79 & -11.73 & -11.73 \\
\hline \multicolumn{6}{|l|}{$\mathrm{DE}$} \\
\hline \multicolumn{6}{|l|}{ Demographics } \\
\hline Immigration volume (\% pop) & 0.07 & 0.12 & 0.00 & 0.12 & 0.00 \\
\hline Dependency ratio & 31.35 & 59.67 & 66.43 & 59.67 & 66.43 \\
\hline \multicolumn{6}{|l|}{ Public finance } \\
\hline Labor income tax (\% points ISS) & - & 0.00 & 7.31 & 0.00 & 7.31 \\
\hline Lump-sum transfer/capita & - & -12.15 & -12.15 & -12.15 & -12.15 \\
\hline \multicolumn{6}{|l|}{ PL } \\
\hline \multicolumn{6}{|l|}{ Demographics } \\
\hline Immigration volume (\% pop) & 0.01 & 0.05 & 0.00 & 0.12 & 0.00 \\
\hline Dependency ratio & 22.21 & 58.81 & 59.74 & 57.70 & 59.74 \\
\hline \multicolumn{6}{|l|}{ Public finance } \\
\hline Labor income tax ( $\%$ points ISS) & - & 0.00 & 1.70 & 0.00 & 3.90 \\
\hline Lump-sum transfer/capita & - & -3.78 & -3.78 & -3.28 & -3.28 \\
\hline \multicolumn{6}{|l|}{ UK } \\
\hline \multicolumn{6}{|l|}{ Demographics } \\
\hline Immigration volume (\% pop) & 0.56 & 0.38 & 0.00 & 0.12 & 0.00 \\
\hline Dependency ratio & 26.51 & 40.48 & 49.04 & 45.81 & 49.04 \\
\hline \multicolumn{6}{|l|}{ Public finance } \\
\hline Labor income tax (\% points ISS) & - & 0.00 & 6.17 & 0.00 & 2.14 \\
\hline Lump-sum transfer/capita & - & -6.04 & -6.04 & -6.23 & -6.23 \\
\hline
\end{tabular}

Cty-Spec Mig Vol: country-specific migration volumes; DE Mig Vol: migration volumes as Germany, relative to population; Mig: corresponding baseline migration scenario; No Mig Tax: immigration end after 2015, increase in labor income taxes for identical public finance deficit (per capita lump-sum transfer) as corresponding Mig cases; see Table 2 for more comments

smaller (5.7 vs. $7.3 \%$ points). The result of the experiment can be summarized as follows:

Finding 2 There are differences across countries in the long-term impact of immigration on public finance which are partially, but not completely, due to differences in the volume of projected immigration. The same (hypothetical) future immigration 
volume in all countries is equivalent to $2.1 \%$ points lower labor income taxes in the UK, $3.9 \%$ points in Poland, $5.7 \%$ points in Austria and $7.3 \%$ points in Germany.

Additional conclusions on cross-country differences can be derived with information contained in finding 1:

Finding 3 Differences in social security institutions across countries contribute to the difference in the long-term impact of immigration on public finance. For instance, future projected immigration flows are equivalent to the same pension benefits gains in the UK and in Germany (benefit ratio about $6 \%$ points higher) but to twice larger gains in retirement age in the UK than in Germany (respectively, 5 and 2.5 years earlier retirement).

Note that one can express finding 3 with other countries. For ease of presentation, we keep our focus on Germany in the discussion of findings 2 and 3, reviewing each pair of countries which involves Germany. A recurrent factor is the age structure of populations. We detail this factor comparing Germany and Austria and briefly mention it for Poland and the UK.

\subsubsection{Differences between Germany and Austria}

Differences in public finance outcomes come from the fact that Germany currently has an older population than Austria. As shown in Table 4, the 2010 old-age dependency ratio is $26 \%$ in Austria and $31 \%$ in Germany (column ISS). Immigrants being younger on average, the end of immigration has then a gradual but more dramatic impact on the dependency ratio in Germany than in Austria: under identical immigration volume projections (columns DE Mig $\mathrm{Vol}$ ), relative to the immigration case the dependency ratio increases $5 \%$ points more when immigration is stopped in Austria (62.8-57.7) and $6.7 \%$ points more in Germany (66.4-59.7). Germany and Austria having comparable institutional settings, but Germany aging faster, a higher increase in labor income taxes is needed in Germany to finance the end of immigration (7.3\% points increase in taxes in Germany, 5.7 in Austria).

A simple arithmetic calculation provides indications that the population age structure is the main driver: if the dependency ratio increased $6.7 \%$ points in Austria (instead of $5 \%$ points) as in Germany and the labor income tax variations were related proportionally to dependency ratio variations, the tax increase in Austria would be $7.6 \%$ points, ${ }^{20}$ close to the increase for Germany.

\subsubsection{Differences between Germany and Poland}

On top of the current population age structure (see differences between Germany and Austria), skill distributions and production structures also matter. With identical immigration volumes, the old-age dependency ratio increases less for Poland than Germany. Using the same arithmetic calculation as for Austria, the labor income tax increase for Poland would however be $12.9 \%$ points if the dependency ratio increased

$207.6=5.7 \times 0.0675 / 0.0504$ 
$6.7 \%$ points in Poland (instead of $2 \%$ points), larger than the 7.3 points tax increase in Germany. Other factors push for a larger tax increase in Poland and counteract the influence of the differences in population age structures ${ }^{21}$ : differences in skill distributions and their impact on tax revenue is one of them; differences in production structures is another one.

Immigrants have a lower skill level than natives in Germany (5\% points fewer high-skilled immigrant households) while they have a higher skill level in Poland (with 19\% points more high-skilled immigrant households). Labor tax schedules being progressive in both countries, skilled workers being more productive and earning more, the end of immigration then leads to a sharper decline in tax revenue in Poland than Germany, and a larger need to compensate the end of immigration with an increase in tax rates, ceteris paribus.

The capital share in production is larger in Poland than in Germany, at 47 versus $37 \%$, respectively. Ceteris paribus, the labor income share, the wage sum and the labor income tax revenues are smaller in Poland. The end of immigration thus triggers the need for a larger tax rate increase to reach the same tax revenue.

\subsubsection{Differences between Germany and the UK}

In addition to the current population age structure (see differences between Germany and Austria), institutional differences also matter, both for findings 2 and 3. Using the same arithmetic calculation as for Austria, the labor income tax increase for the UK would be $4.5 \%$ points if the dependency ratio increased $6.7 \%$ points in the UK (instead of $3.2 \%$ points), smaller than the 7.3 points increase in Germany. On top of differences in population age structures, other factors also explain why taxes need to be increased more in Germany.

Population aging is less of a challenge in the UK than Germany. On the one hand, the old-age dependency ratio remains comparatively low in the UK, in 2010 as well as in 2060 with or without immigration (26\% in 2010 and $49 \%$ in 2060 for the UK, compared to 31 and $66 \%$ respectively for Germany). On the other hand, the UK pension system has a Beveridgean nature, with a lower and flatter replacement rate and a focus on minimum income, while Germany has a Bismarckian pension system with a strong earnings-related component. As a result, aggregate pension expenditures are lower in the UK ( $8 \%$ of GDP in 2010 for the UK versus $12 \%$ of GDP for Germany). Thus, slower population aging and a cheaper pension system reduce the need to increase taxes in the UK, with or without immigration, which explains finding 2.

Other characteristics of the pension system explain finding 3, namely Gruber-Wise incentives: early retirement is more heavily penalized and postponed retirement more heavily rewarded in the UK than in Germany (see OECD 2013). When the end of immigration is financed with higher labor income taxes, which are changed for all age classes in the same proportion, the difference in Gruber-Wise incentives plays

\footnotetext{
21 Population age structure differences push to a smaller tax increase for Poland than Germany. Only if the Polish tax increase (with counterfactual immigration volumes) was smaller than $3.9 \%$ points could the simple arithmetic computation lead to a tax increase close to the 7.3 points of Germany. Some factors push for a larger tax increase in Poland, ceteris paribus.
} 
no important role. This difference also plays no important role when the end of immigration is financed with lower pension benefit ratios. However, the difference in Gruber-Wise incentives plays a significant role when the end of immigration is financed with postponed retirement age: ceteris paribus, households in the UK get higher pension benefit rewards than German households; hence, a further increase in retirement age in the UK is needed to finance these additional benefits. This explains why immigration brings about larger retirement age gains in the UK than Germany, but only comparable pension benefit gains.

\section{Policy implications}

We provide context and four groups of implications relevant for policy analysis and design, derived from results and analysis in Sect. 4.

\subsection{Context}

Immigration policy has long been an emotional topic of policy debate at the national level. European countries also discuss and define joint control of immigration. Initially implemented by seven members of the European Union in 1995, the Schengen Agreement eliminates internal border controls and establishes a common visa policy. Gradually, other countries have signed the agreement: 20 years later, 26 European countries are members of the Schengen Area. In its 2015 work program, the executive branch of the European Union has listed migration policy as one of its 10 priorities, pushing beyond political asylum and security to include long-term demographic challenges (European Commission 2014).

\subsection{Immigration contribution}

Future immigration has a positive contribution to the long-term financing of old-age social security expenditures with an aging population in Europe. This result is qualitatively consistent with the existing literature (see Table 1). ${ }^{22}$ Because immigrants are younger on average, a permanent immigration inflow increases the share of households who contribute to social security and reduces the share of households who benefit from it. The resulting broadening of the tax base allows for a relative reduction of tax rates, increase of pension benefits or decrease of the statutory retirement age.

\subsection{Size of immigration contribution}

To what extent immigration contributes to long-term public financing depends on demographic, institutional and labor market characteristics of the country. The analysis

\footnotetext{
22 Schou (2006) is the only general equilibrium analysis having a different qualitative result. See the discussion in Schou (2006) for possible explanations.
} 
in Sect. 4.2 shows that the same volume of immigration has a larger contribution to long-term public finance when...

- the population is old (with a large old-age dependency ratio); or

- immigrants are comparatively younger than the native population; or

- the average skill level of workers is higher for immigrants (leading to a higher increase in public finance revenue); or

- the pension system has a strong earnings-related component (typical of Bismarckian systems) as opposed to a focus on minimum income guarantees (typical of Beveridgean systems).

Immigration is however not sufficient to ensure the financing of old-age social security expenditures with an aging population, because effects are not linear. ${ }^{23}$ To finance oldage expenditures, reforms appear unavoidable (for a review of options, see Bovenberg 2003).

\subsection{Policy complementarity}

The institutional setup and labor markets influence the joint design of immigration policy and old-age social security. Future immigration flows provide the same retirement age benefits in Austria and the UK (+5 years needed in 2060 if immigration stops after 2015) but different pension payment benefits ( $-15 \%$ points in the pension replacement rate in 2060, respectively, -6 points, with no immigration after 2015), because of financial incentives for postponed retirement in the UK (see finding 1 for more). Pro-immigration policies can be combined with pension reforms which benefit the native population to secure popular support. The choice of the pension reform depends on complementarity effects. If pro-immigration policy reforms are combined with gains in retirement duration, they are equally likely to win popular support in the UK and in Austria, ceteris paribus. If on the other hand pro-immigration reforms are associated with larger pension benefits, popular support is more likely in Austria than in the UK.

\subsection{Cross-country policy heterogeneity}

Immigration policy differs across European countries, as illustrated for instance during the 2015 European refugee crisis. ${ }^{24}$ Why some countries are more open to immigration than others is an open research question, the literature searching for the determinants of immigration policy (for a critical review, see Ceobanu and Escandell 2010). Our longterm public finance analysis provides another rationale for cross-country differences in

\footnotetext{
23 Unreported simulations show that a doubling of the projected immigration flow in Germany would only reduce the yearly social security deficit by $1 \%$ points of GDP in 2060: doubling the flow would move the deficit from $10.5 \%$ of GDP to $9.5 \%$ of GDP.

24 Our simulations would need to be updated to estimate the impact of the refugee crisis, a temporary increase in immigration flows. First, the volumes are larger and effects are not linear. Second, the skill distribution may vary, with more low-skilled immigrations. The crisis still illustrates the cross-country differences in policy stance.
} 


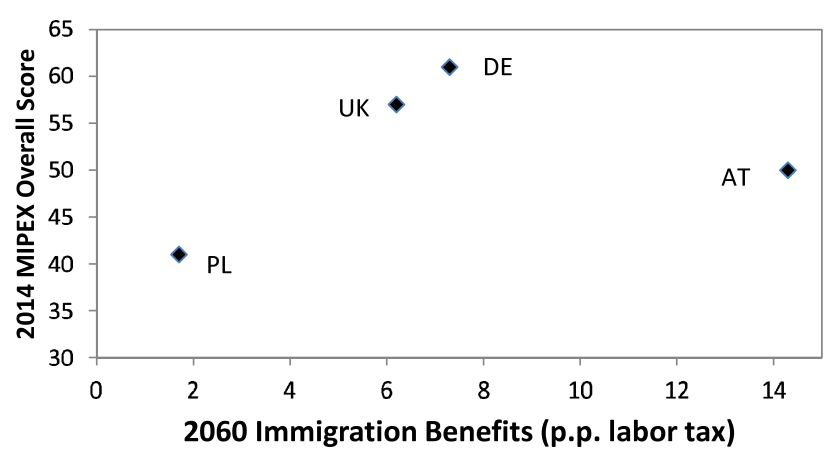

Source: Huddleston et al. (2015), own simulations

Fig. 3 Immigration financial contribution and migrants integration policy index

immigration policy, namely the long-term public finance contribution of immigration, which can be small or large. Countries with a higher long-term contribution of future immigration may be more open to immigrants today. Leaving empirical analysis for future research, Fig. 3 illustrates the potential of such an explanation. The figure compares our quantitative estimates of the contribution of immigration to the longterm financing of old-age social security expenditures (where benefits are expressed in terms of labor income taxes gains; see finding 1) with a comprehensive index of immigrants integration policy (MIPEX; see Huddleston et al. 2015). Although the correlation is not perfect, it is positive: the larger the long-term public finance benefit, the stronger the migrants integration policy.

\section{Concluding remarks}

Because immigrants are younger, immigration flows could help finance old-age social security expenditures in developed countries with an aging population. The contribution of future immigration to the financing of these expenditures varies by countries, depending on the volume of immigration, the institutional setup and other factors. General equilibrium estimates provided so far in the literature have been calculated with the use of different models, preventing comparisons across countries. We use the same overlapping-generations model to provide comparable estimates and analyze the source of differences.

For the same hypothetical immigration volume, we find that the contribution of future immigration is equivalent to $2.1 \%$ points labor income taxes in the UK, 3.9 points in Poland, 5.7 points in Austria and 7.3 points in Germany in 2060. These variations may in part explain differences in immigration policy stances across the European Union.

Drivers for cross-country differences depend on the characteristics of each country and of the immigration flows. Among important factors are: a pension system focused on minimum income with a small earnings-related part for the UK; high skill content in immigration flows balanced with a currently young population for Poland; high 
pension replacement rate with a strong earnings-related component in pensions for Austria; and a strong earnings-related component in pensions with an old population and low skill content in immigration flows for Germany.

Acknowledgments Open access funding provided by Institute for Advanced Studies Vienna. We thank Helmut Hofer, Christian Keuschnigg, Stefan Moog, Michael Reiter, Rudolf Winter-Ebmer, participants at the 2013 European Workshop on Labour Markets and Demographic Change, as well as two anonymous referees and the editor for useful comments and suggestions. Funding by the Oesterreichische Nationalbank (Anniversary Fund Project Number 13800) is gratefully acknowledged. Disclaimer: Opinions expressed in this paper do not necessarily reflect the official views of the Oesterreichische Nationalbank nor the Austrian Fiscal Advisory Council.

Open Access This article is distributed under the terms of the Creative Commons Attribution 4.0 International License (http://creativecommons.org/licenses/by/4.0/), which permits unrestricted use, distribution, and reproduction in any medium, provided you give appropriate credit to the original author(s) and the source, provide a link to the Creative Commons license, and indicate if changes were made.

\section{References}

Ageing Working Group. (2012). The 2012 Ageing Report: Economic and budgetary projections for the 27 EU Member States (2010-2060). Joint Report European Commission and Economic Policy Committee, vol 2, European Economy.

Algan, Y., Dustmann, C., Glitz, A., \& Manning, A. (2010). The economic situation of first and secondgeneration immigrants in France, Germany and the United Kingdom. Economic Journal, 120(542), 4-30.

Andolfatto, D. (1996). Business cycles and labor-market search. American Economic Review, 86(1), 112132.

Annabi, N., Fougere, M., \& Harvey, S. (2009). Inter-temporal and inter-industry effects of population ageing: A general equilibrium assessment for Canada. Labour, 23(4), 609-651.

Auerbach, A. J., \& Kotlikoff, L. J. (1987). Dynamic Fiscal Policy. Cambridge: Cambridge University Press.

Berger, J., Davoine, T., Schuster, P., \& Strohner, L. (2016). Cross-country differences in the contribution of future migration to old-age financing - Technical Appendix. February 2016.

Blanchard, O. J. (1985). Debt, deficits, and finite horizons. Journal of Political Economy, 93(2), 223-247.

Boone, J., \& Bovenberg, L. (2002). Optimal labour taxation and search. Journal of Public Economics, $85(1), 53-97$

Borjas, G. J. (1992). Ethnic capital and intergenerational mobility. The Quarterly Journal of Economics, 107(1), 123-150.

Borjas, G. J. (1994). The economics of immigration. Journal of Economic Literature, 32(4), 1667-1717.

Borjas, G. J. (2003). The labor demand curve is downward sloping: Reexamining the impact of immigration on the labor market. The Quarterly Journal of Economics, 118(4), 1335-1374.

Borjas, G. J., Grogger, J., \& Hanson, G. H. (2008). Imperfect substitution between immigrants and natives: A reappraisal. NBER Working Papers 13887.

Bovenberg, A. L. (2003). Financing retirement in the European Union. International Tax and Public Finance, 10(6), 713-734.

Buiter, W. H. (1997). Generational accounts, aggregate saving and intergenerational distribution. Economica, 64(256), 605-626.

Ceobanu, A. M., \& Escandell, X. (2010). Comparative analyses of public attitudes toward immigrants and immigration using multinational survey data: A review of theories and research. Annual Review of Sociology, 36, 309-328.

Chojnicki, X., Docquier, F., \& Ragot, L. (2011). Should the US have locked heaven's door? Journal of Population Economics, 24(1), 317-359.

de la Croix, D., Pierrard, O., \& Sneessens, H. R. (2013). Aging and pensions in general equilibrium: Labor market imperfections matter. Journal of Economic Dynamics and Control, 37(1), 104-124.

European Commission (2014). Commission work programme 2015: A new start. COM(2014) 910 final, Strasbourg. 
Eurostat (2011). Population projections, Europop 2010. http://epp.eurostat.ec.europa.eu/portal/page/portal/ population/data/database.

Fehr, H., Jokisch, S., \& Kotlikoff, L. (2003). The developed world's demographic transition - the roles of capital flows, immigration, and policy. NBER Working Papers 10096.

French, E. (2005). The effects of health, wealth, and wages on labour supply and retirement behaviour. Review of Economic Studies, 72(2), 395-427.

Gertler, M. (1999). Government debt and social security in a life-cycle economy. Carnegie-Rochester Conference Series on Public Policy, 50(1), 61-110.

Gruber, J., \& Wise, D. (2005). Social security programs and retirement around the world: Fiscal implications, introduction and summary. NBER Working Papers 11290.

Hayashi, F. (1982). Tobin's marginal q and average q: A neoclassical interpretation. Econometrica, 50(1), 213-224.

Heckman, J., Lochner, L., \& Taber, C. (1998). Explaining rising wage inequality: Explorations with a dynamic general equilibrium model of labor earnings with heterogeneous agents. Review of Economic Dynamics, 1(1), 1-58.

Huddleston, T., Bilgili, O., Joki, A. L., \& Vankova, Z. (2015). Migrant integration policy index 2015. www. mipex.eu.

Immervoll, H., Kleven, H. J., Kreiner, C. T., \& Saez, E. (2007). Welfare reform in European countries: A microsimulation analysis. Economic Journal, 117(516), 1-44.

Izquierdo, M., Jimeno, J., \& Rojas, J. (2010). On the aggregate effects of immigration in Spain. SERIEs, 1(4), 409-432.

Jaag, C. (2009). Education, demographics, and the economy. Journal of Pension Economics and Finance, $8(02), 189-223$.

Jaag, C., Keuschnigg, C., \& Keuschnigg, M. (2010). Pension reform, retirement, and life-cycle unemployment. International Tax and Public Finance, 17(5), 556-585.

Krusell, P., Ohanian, L. E., Rios-Rull, J. V., \& Violante, G. L. (2000). Capital-skill complementarity and inequality: A macroeconomic analysis. Econometrica, 68(5), 1029-1054.

Magnani, R. (2011). A general equilibrium evaluation of the sustainability of the new pension reforms in Italy. Research in Economics, 65(1), 5-35.

Mayda, A. M. (2006). Who Is against immigration? A cross-country investigation of individual attitudes toward immigrants. The Review of Economics and Statistics, 88(3), 510-530.

OECD. (2013). Pensions at a glance 2013: OECD and G20 indicators. Paris: OECD Publishing.

Ottaviano, G. I. P., \& Peri, G. (2012). Rethinking the effect of immigration on wages. Journal of the European Economic Association, 10(1), 152-197.

Schou, P. (2006). Immigration, integration and fiscal sustainability. Journal of Population Economics, 19(4), 671-689.

Sinn, H. W. (2000). EU enlargement, migration, and lessons from German unification. German Economic Review, 1(3), 299-314.

Storesletten, K. (2000). Sustaining fiscal policy through immigration. Journal of Political Economy, 108(2), $300-323$.

Weil, P. (1990). Nonexpected utility in macroeconomics. The Quarterly Journal of Economics, 105(1), 29-42.

Zimmermann, K. (2005). European labour mobility: Challenges and potentials. De Economist, 153(4), $425-450$. 